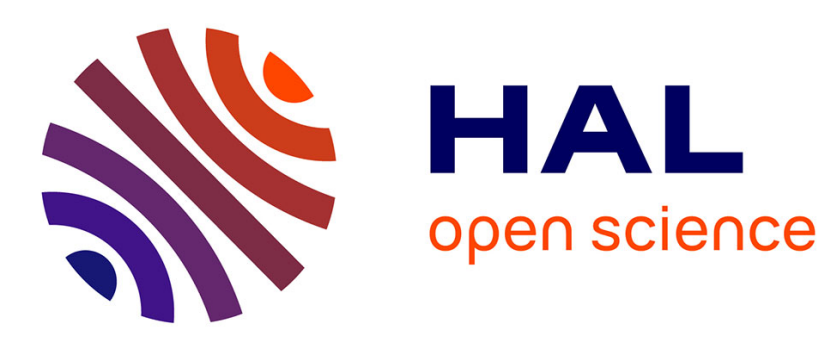

\title{
A new species of Olopachys Berlese (Acari: Pachylaelapidae) from Iran with a key to the world species
}

Samaneh Mojahed, Jalil Hajizadeh, Reza Hosseini, Ali Ahadiyat

\section{- To cite this version:}

Samaneh Mojahed, Jalil Hajizadeh, Reza Hosseini, Ali Ahadiyat. A new species of Olopachys Berlese (Acari: Pachylaelapidae) from Iran with a key to the world species. Acarologia, 2019, 59 (1), pp.46-56. 10.24349/acarologia/20194313 . hal-01996618

\section{HAL Id: hal-01996618 https://hal.science/hal-01996618}

Submitted on 28 Jan 2019

HAL is a multi-disciplinary open access archive for the deposit and dissemination of scientific research documents, whether they are published or not. The documents may come from teaching and research institutions in France or abroad, or from public or private research centers.
L'archive ouverte pluridisciplinaire HAL, est destinée au dépôt et à la diffusion de documents scientifiques de niveau recherche, publiés ou non, émanant des établissements d'enseignement et de recherche français ou étrangers, des laboratoires publics ou privés.

\section{(c)(1)}

Distributed under a Creative Commons Attribution| 4.0 International License 


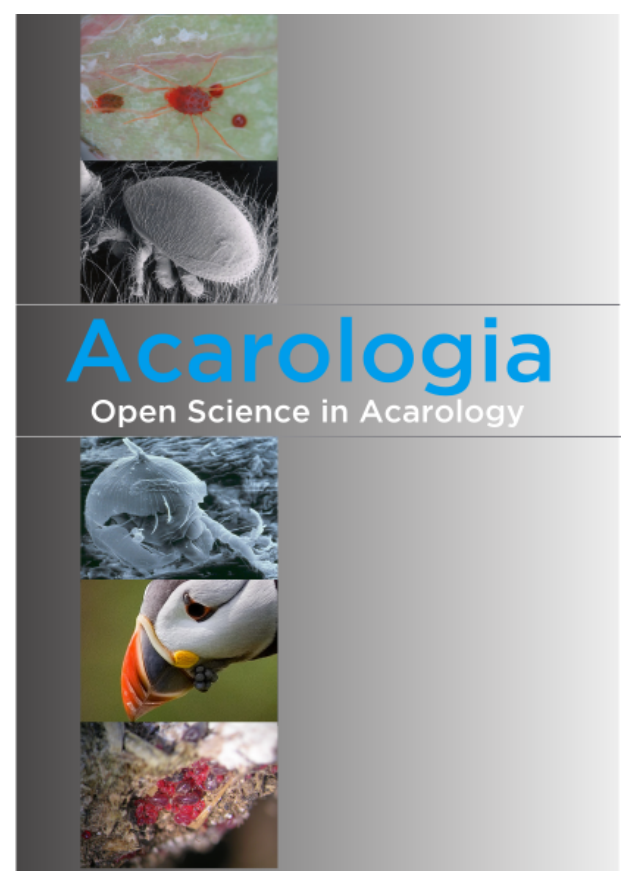

\section{Acarologia}

A quarterly journal of acarology, since 1959

Publishing on all aspects of the Acari

All information:

http://www1.montpellier.inra.fr/CBGP/acarologia/ acarologia@supagro.inra.fr

\section{OPEN ACCESS}

\section{Acarologia is proudly non-profit, with no page charges and free open access}

Please help us maintain this system by encouraging your institutes to subscribe to the print version of the journal and by sending us your high quality research on the Acari.

Subscriptions: Year 2019 (Volume 59): $450 €$ http://www1.montpellier.inra.fr/CBGP/acarologia/subscribe.php

Previous volumes (2010-2017): $250 €$ / year (4 issues)

Acarologia, CBGP, CS 30016, 34988 MONTFERRIER-sur-LEZ Cedex, France

The digitalization of Acarologia papers prior to 2000 was supported by Agropolis Fondation under the reference ID 1500-024 through the « Investissements d'avenir » programme

(Labex Agro: ANR-10-LABX-0001-01)
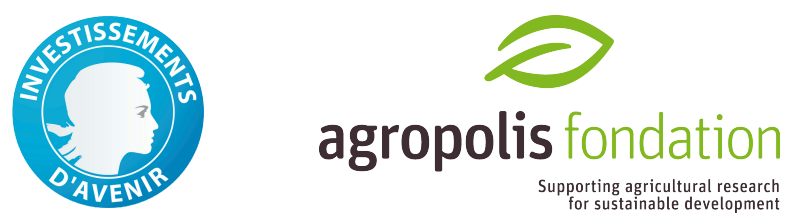

Acarologia is under free license and distributed under the terms of the

Creative Commons-BY-NC-ND which permits unrestricted non-commercial use, distribution, and reproduction in any medium, provided the original author and source are credited. 


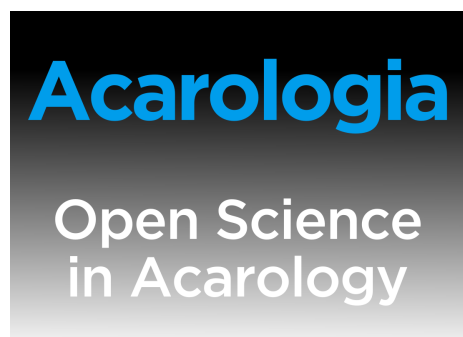

\section{A new species of Olopachys Berlese (Acari: Pachylaelapidae) from Iran with a key to the world species}

\author{
Samaneh Mojahed $^{a}$, Jalil Hajizadeh $^{a}$, Reza Hosseini $^{a}$, Ali Ahadiyat ${ }^{b}$ \\ ${ }^{a}$ Department of Plant Protection, Faculty of Agricultural Sciences, University of Guilan, Rasht, Iran. \\ ${ }^{b}$ Department of Plant Protection, Science and Research Branch, Islamic Azad University, Tehran, Iran.
}

\section{Original article}

\section{ABSTRACT}

A new species, Olopachys iraniensis n. sp. (Mesostigmata: Pachylaelapidae) is described based on adult females collected from soil in Guilan Province, northern Iran. Two identification keys are provided, one for all known species of Olopachys, and the other for species recorded from Iran. A brief review on pachylaelapid mites of Iran is also provided.

Keywords Acari; Olopachys; Pachylaelapidae; new species; soil; Guilan

Zoobank http://zoobank.org/7D80D390-FE33-46A5-B60C-D37C36D61A6D

\section{Introduction}

Mites of the family Pachylaelapidae Berlese, 1913 are free-living predatory mites that feed on arthropods and soil-dwelling nematodes. In total, approximately 250 species and 16 genera of Pachylaelapidae have been recorded worldwide (Mašán and Halliday 2014). Until now, 25 recorded and described species of pachylaelapid mites are known from Iran (Khanjani and Kamali 2000a, b; Kamali et al. 2001; Ahmadi 2002; Jalaeian et al. 2004; Rahmani et al. 2006; Ahangaran et al. 2010; Babaeian and Kazemi 2011; Kazemi and Ahangaran 2011; Ahadiyat and Cheraghali 2012; Nazari-Tajani et al. 2012; Ahangaran et al. 2012; Ahadiyat et al. 2014; Ahadiyat et al. 2016; Babaeian et al. 2016a, b; Mojahed et al. 2017; Mašán et al. 2018; this study). Guilan Province, in northern Iran, can be considered as one of the most diverse region for Pachylaelapidae in Iran, with 13 found species (Nazari-Tajani et al. 2012; Mojahed et al. 2017; Mašán et al. 2018; this study).

Olopachys is a relatively small genus that currently includes 22 described species from the Western Palaearctic Region (Berlese 1910; Sellnick 1950; Reitblatt 1958; Koroleva 1976; Mašán 2007a, 2007b; Özbek 2014; Özbek and Halliday 2015; Özbek 2016). Olopachys was redefined by Koroleva (1977), Karg (1993), Mašán (2007a, 2007b) and Mašán and Halliday (2014) and treated as a genus by these authors, although Berlese (1910) had originally considered it as a subgenus of Pachylaelaps. In adult females of Olopachys, anal and genitiventral shields are fused together into a genitiventrianal shield, which does not exist in other pachylaelapid genera. Another distinguishing feature for the genus is the shape of the tubes of the sperm access system (Koroleva 1976, 1977; Karg 1993; Mašán 2007a, 2007b).

The Olopachys fauna of Iran is poorly known, with only two species reported from a total of six provinces (Azerbaijan, Golestan, Guilan, Khorasan, Mazandaran and Tehran), namely Olopachys caucasicus Koroleva, 1976 and Olopachys compositus Koroleva, 1976 (Ahangaran et al. 2010; Kazemi and Ahangaran 2011; Ahadiyat and Cheraghali 2012; Zakeri et al. 2012; Kazemi et al. 2012; Nazari-Tajani et al. 2012; Kazemi and Rajaei 2013; Mohammad-DustarSharaf et al. 2016a, b; Rezaie et al. 2016; Saberi et al. 2016; Mojahed et al. 2017). Here we describe a new soil-dwelling species of Olopachys from Guilan Province, northern Iran. In addition, we also provide (1) an identification key to Olopachys species (females) of Iran, (2) a 
key to the world species of the subgenus Olopachys (Olopachys) and (3) a tabulated checklist for pachylaelapid species found in Iran.

\section{Materials and methods}

Mite specimens were collected from soil under poplar and pine trees in Guilan Province, forest areas of the Emamzadeh Hashem in Rasht County and soil under citrus trees in Langrud County. After extraction using Berlese-Tullgren funnels, the mites were removed under a stereomicroscope, preserved in $75 \%$ ethanol, cleared in Nesbitt's fluid and then mounted on microscope slides in Hoyer's medium. Morphological observations, measurements, and illustrations were made using a compound microscope equipped with differential interference contrast and phase contrast optical systems, and a drawing tube. Photos were taken using a Canon Camera DS126311, attached to the microscope. Measurements are given in micrometers $(\mu \mathrm{m})$; each measurement corresponds to the average followed (in parentheses) by the respective ranges. Lengths of dorsal, sternal, and genitiventrianal shields were measured from the anterior to posterior margins along their midlines. Maximum widths of dorsal and genitiventrianal shields were taken at their widest points. Width of sternal shield was measured at the mid-level of coxae II. Lengths of dorsal setae were measured from bases of their insertions to their tips. Terminology for dorsal and ventral idiosomal chaetotaxy used in this paper follows that of Lindquist and Evans (1965). Identification of pore-like structures on the idiosomal integument is based on the morphological observations of Athias-Henriot (1969); notation for these structures such as adenotaxy and poroidotaxy follows Johnston and Moraza (1991) and Moraza and Pena (2005). Leg setal notation and chaetotactic formulae are based on Evans (1963). Holotype and two female paratypes of the new species are deposited in the Acarology Laboratory, Department of Plant Protection, Faculty of Agricultural Sciences, University of Guilan, Iran. One paratype female will be deposited in the Acarological Collection, Jalal Afshar Zoological Museum, Department of Plant Protection, Faculty of Agriculture, University of Tehran, Karaj, Iran. The checklist of Pachylaelapidae of Iran is arranged alphabetically according to genera. For each species, only the first record of the species in the literature, for Iran, is cited; further reports of the same species are not mentioned in the checklist.

\section{Results}

\section{Olopachys iraniensis n. sp. Genus Olopachys Berlese, 1910 Pachylaelaps (Olopachys) Berlese, 1910: 256.}

Zoobank: E217FB12-5254-4D51-AA22-CD408ABEDC31

Type species: Pachylaelaps (Olopachys) scutatus Berlese, 1910, by original designation. The genus was re-described in detail by Mašán (2007a, 2007b).

\section{Olopachys iraniensis $\mathbf{n} . \mathbf{s p}$. (Figures 1-3, 4C)}

\section{Diagnosis (Female)}

Movable digit of chelicera with a subterminal tooth and terminal hook, fixed digit with two subterminal teeth and distal hook; base of epistome finely denticulated lateraly, epistome with narrow subdistal neck and long apical serration; posterolateral margins of dorsal idiosoma with one pair of gland pores ( $g d S 4$ ); clunal setae $J 5$ minute; genitiventrianal shield longer than wide, length/ width ratio: 1.3 (1.26-1.33), spermathecal tubes hyaline, hook-like, stout, relatively long, with well indicated and observable ductus; soft dorsolateral and opisthogastric integument bearing 14 pairs of setae $(r 6, R 1, R 3-R 8, J V 3-J V 5, Z V 2-Z V 4)$ and four pairs of poroids (ivo1, ivo2, ivo3, ivp); tarsus II with two spur-like distal setae (pll, pl2). 


\section{Description. Female $(n=4)$}

Dorsal idiosoma (Fig. 1A) - Dorsal shield 669 (616-715) long, 403 (385-420) wide, length/width ratio: 1.7 (1.6-1.7), oval-shaped, ornamented with reticular pattern; with twelve pairs of poroids (idj4, idj6,idJ1,idJ2,idJ4,ids4,idS3,idS4,idS5,idz6,idZ2,idZ3); a pair of gland pores $(g d S 4)$ present on posterolateral margins, $g d Z 1$ subcircular and well separated from gdS4; shield bearing 30 pairs of setae, smooth and needle-like, clunal setae $J 5$ minute, other setae long. Lengths of dorsal setae: j1 25 (24-26), j2 67 (62-72), j3 79 (78-80), j4 72 (72-74), j5 51 (48-54), j6 84 (78-88), J1 91 (90-94), J2 88 (82-93), J3 86 (78-96), J4 83 (80-90), J5 9 (8-10), z1 52 (48-55), z2 88 (86-90), z4 102 (100-106), z5 65 (62-68), z6 94 (90-96), Z1 93 (88-98), Z2 98 (96-100), Z3 99 (94-104), s2 80 (76-84), s4 95 (88-100), s5 95 (88-100), s6 65 (60-68), S1 51 (50-54), S3 25 (24-28), S4 90 (86-93), S5 89 (84-93).

Ventral idiosoma (Fig. 1B) - Sternal shield 217 (208-228) long, 116 (96-135) wide, reticulate and bearing four pairs of setae $s t 1-4$ and three pairs of poroids $(i v 1, i v 2, i v 4)$; shield posterior margin concave, reaching level of posterior margin of coxae IV. Length of setae: st 1 77 (68-83), st2 73 (68-80), st3 61 (52-67) and st4 71 (68-73). Genitiventrianal shield 327
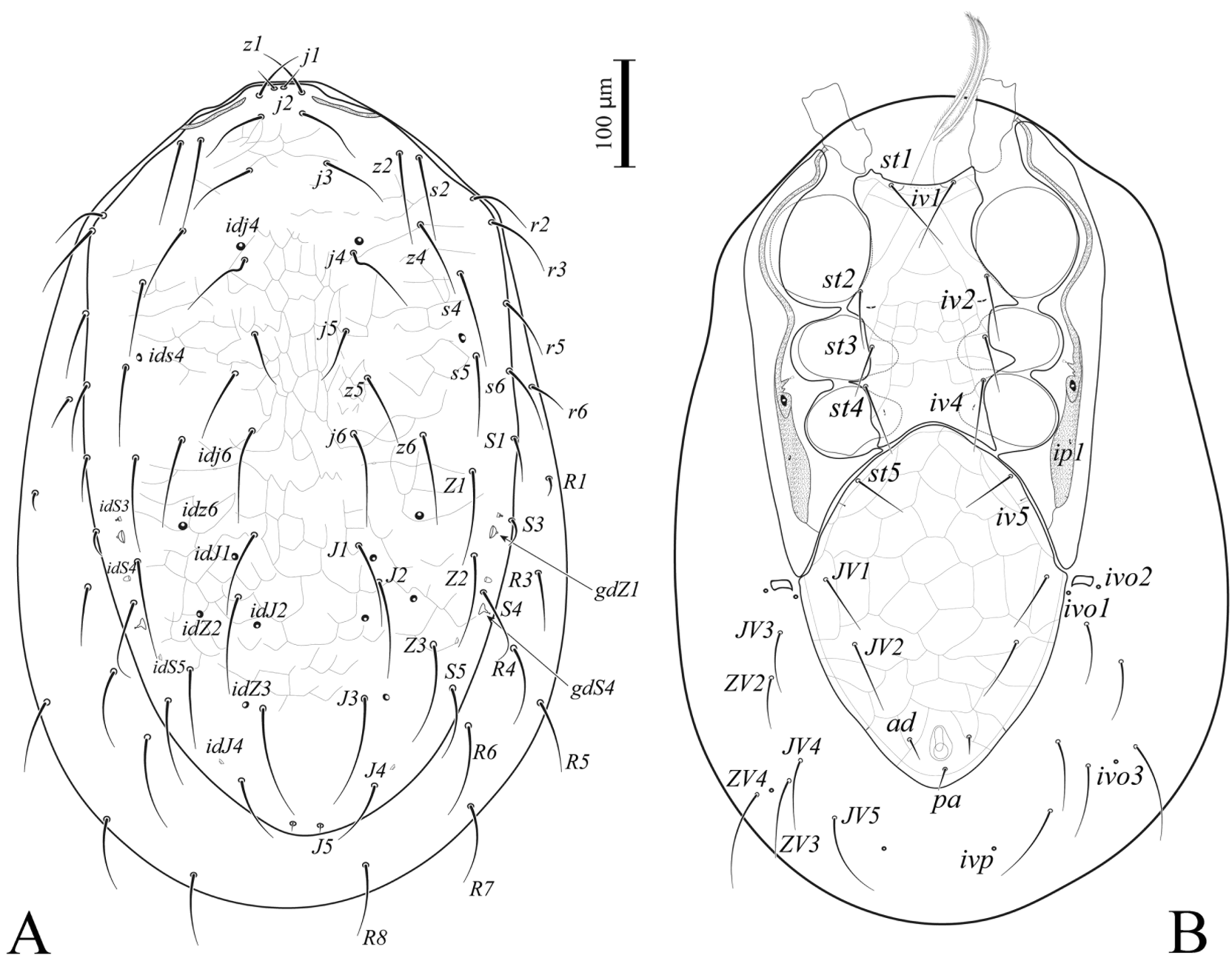

Figure 1 Olopachys iraniensis n. sp. (female): A - Dorsal idiosoma; B - Ventral idiosoma. Scale bar: $100 \mu \mathrm{m}$. 
(304-348) long, 253 (240-260) wide, longer than wide, length/ width ratio: 1.3 (1.26-1.33), abutting sternal shield anteromesally, suboval, reticulate throughout and bearing genital setae st5 70 (68-72), with two pairs of opisthogastric setae JV1 71 (68-76), JV2 70 (64-80), one pair of pore (iv5) and three short circumanal setae. Metapodal plates small and oval. Dorsolateral and opisthogastric soft integument with eight pairs of marginal [r6 47 (46-48), R1 15 (14-16), $R 342$ (40-44), R4 43 (42-44), R5 75 (74-76), R6 71 (64-80), R7 75 (74-76), R8 75 (74-76)] and six pairs of opisthogastric setae [ JV3 68 (66-70), JV4 58 (56-60), JV5 87 (86-88), ZV2 70 (68-72), ZV3 88 (86-90), ZV4 77 (76-78)], respectively. Opisthogastric integument bearing four pairs of poroids (ivo1, ivo2, ivo3, ivp).

Gnathosoma - Hypostomal seta $h 331$ (28-34) and $h 130$ (28-33) over twice longer than h2 13 (12-15) and palpcoxal setae pc 11 (10-14); corniculi elongated 77 (76-80) and horn-like (Fig. 2A); six transverse rows of denticles, followed posteriorly by a smooth ridge. Palptarsus with 3-tined apotele (Fig. 2B). Epistome with finely denticulate anterolateral margins, median process neck-like, concave laterally, with apical serration of elongate denticles (Fig. 2C). Movable digit of chelicera 62 (60-64), with large subterminal tooth and distal hook; fixed digit 47 (45-49) with two subterminal teeth and tridentate distal hook; pilus dentilis not seen (Fig. $3 \mathrm{~A})$.

Spermathecal apparatus (Fig. 3B) - Sperm access system associated with coxae IV. Tubes of sperm induction system hyaline, well-developed, stout and slightly curved (somehow comma-shaped) with thin ductus inside.

Legs (Fig. 3C) - Legs normal, shorter than idiosoma. Tarsus I-IV with ambulacrum and two claws. Female tarsus II with two spur-like distal setae $(p l 1, p l 2)$. Leg lengths (including pretarsi): I 496 (464-520); II 450 (400-544); III 366 (336-408); IV 502 (472-544). Leg IV is the longest and leg III is the shortest one. Legs IV and I longer than legs II and III. Leg chaetotaxy normal for the genus. Leg I: coxa 1-1/0-1/1-0; trochanter 1-1/2-0/1-1; femur 2-2/3-3/1-2; genu 2-3/3-1/2-2; tibia 2-3/2-1/2-2; leg II: coxa $0-0 / 0-0 / 1-0$; trochanter $1-2 / 1-0 / 0-1$; femur

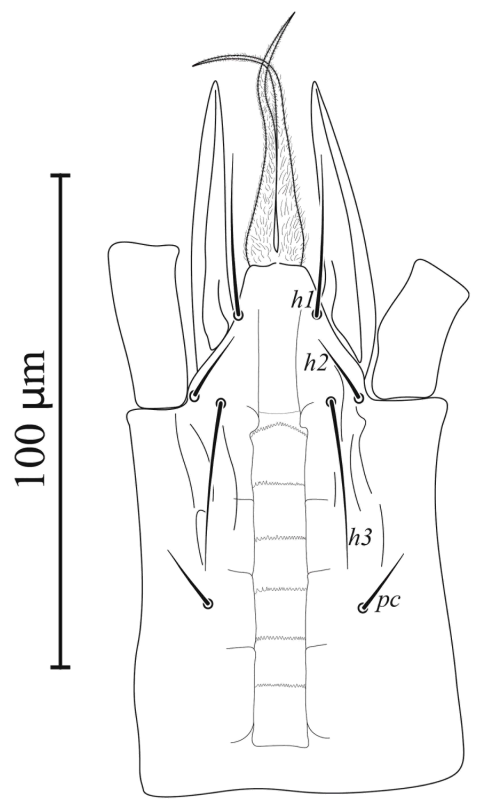

A

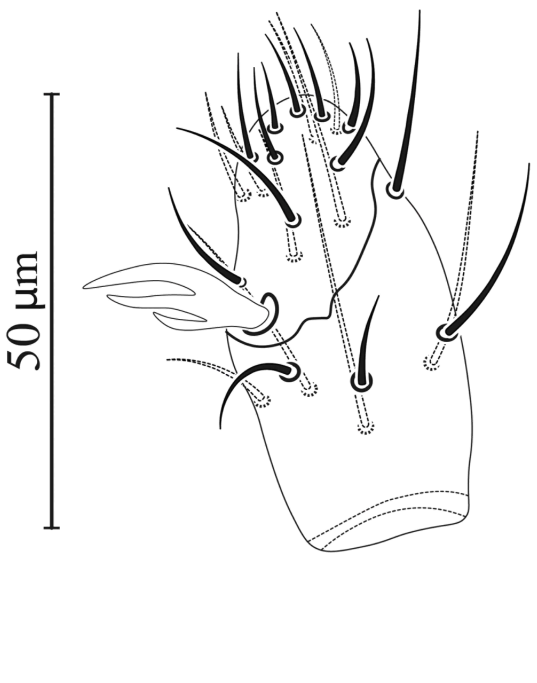

B

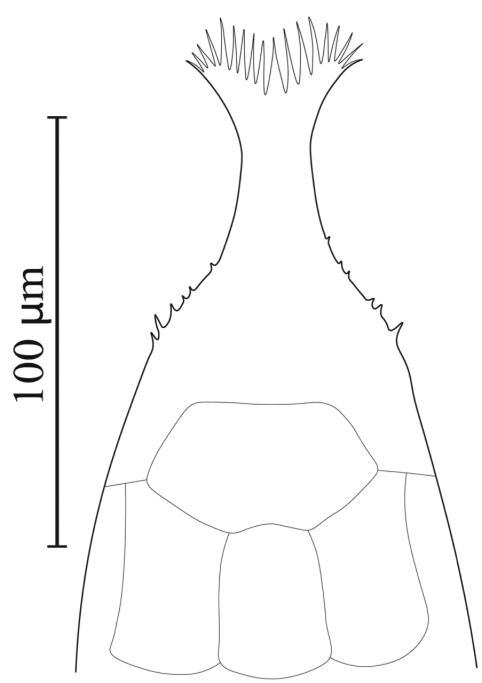

$\mathcal{C}$

Figure 2 Olopachys iraniensis n. sp. (female): A - Ventral gnathosoma; B - Palp tarsus; C - Epistome. Scale bar: $100 \mu \mathrm{m}$ for A and C; 50 $\mu \mathrm{m}$ for B. 
2-2/3-1/2-1; genu 2-3/2-2/0-2; tibia 2-3/1-0/2-2, tarsus 3-3/4-3/2-3; leg III: coxa 0-0/0-0/0-0; trochanter 1-2/1-0/0-1; femur 1-2/1-0/1-1; genu 1-2/2-0/1-1; tibia 1-2/1-1/1-1, tarsus 3-4/3-2/33 ; leg IV: coxa 0-0/0-0/0-0; trochanter 1-1/0-0/2-1; femur 1-2/1-0/1-1; genu 1-2/2-0/1-1; tibia $1-1 / 2-1 / 1-1$, tarsus 3-3/4-3/2-3.

Male. Not found.

Etymology - The specific name of the new species refers to Iran, the country where the type specimens were collected.

Remarks - Olopachys iraniensis n. sp. was found in temperate and humid climate and in the lowland area at an altitude of $113 \mathrm{~m}$ a.s.l. This species is similar to O. digitus Özbek, 2016; O. prolixus Özbek and Halliday, 2015; O. ovatus Özbek and Halliday, 2015 and $O$. vlastae Mašán, 2007 in having minute J5, two spur like distal setae on tarsus II, and a pair of gland pores on posterolateral margin of dorsal shield ( $g d S 4)$, but this new species can be easily separated from $O$. digitus, O. prolixus and $O$. ovatus by the presence of longer and curved spermathecal ducts and from $O$. vlastae by shorter hooke-like and spaced spermathecal tubes. Olopachys iraniensis $\mathrm{n}$. sp. has also different number of the lateral and opisthogastric setae (14 pairs) than O. prolixus (11 pairs), O. ovatus and O. vlastae (12 pairs) and O.digitus (13 pairs).

Type material - Holotype: female, Iran, Guilan Province, Rasht County, Forest areas of

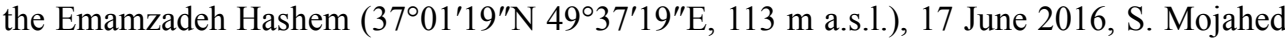
coll., in soil under poplar tree (Populus caspica, Bornm.). Paratypes: one female, with the same location as the holotype, 11 July 2015, S. Mojahed coll., in soil under pine trees (Pinus halepensis Miller); two females Guilan Province, Langrud County $\left(37^{\circ} 11^{\prime} 0^{\prime \prime} \mathrm{N}, 50^{\circ} 9^{\prime} 0^{\prime \prime} \mathrm{E}\right), 6$ October 2011, J. Hajizadeh coll., in soil under orange trees (Citrus sinensis (L.) Osbeck).

\section{Key to world species of the subgenus Olopachys (Olopachys) (females)}

The key to the world species of the subgenus Olopachys (Olopachys) presented by Özbek (2016) is modified here to accommodate the new species from Iran. The specimens of Olopachys
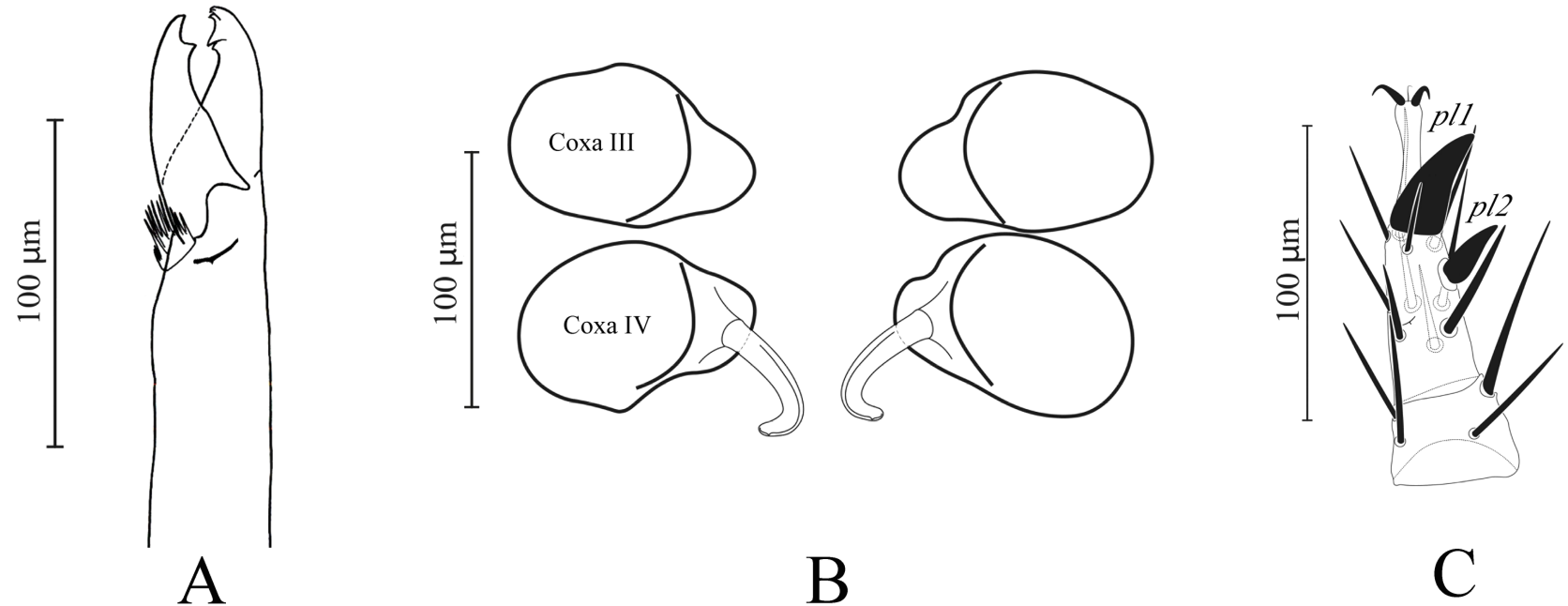

Figure 3 Olopachys iraniensis n. sp. (female): A - Chelicera; B - sperm access system; C - tarsus II. Scale bar: $100 \mu \mathrm{m}$. 


\section{Acarologia}
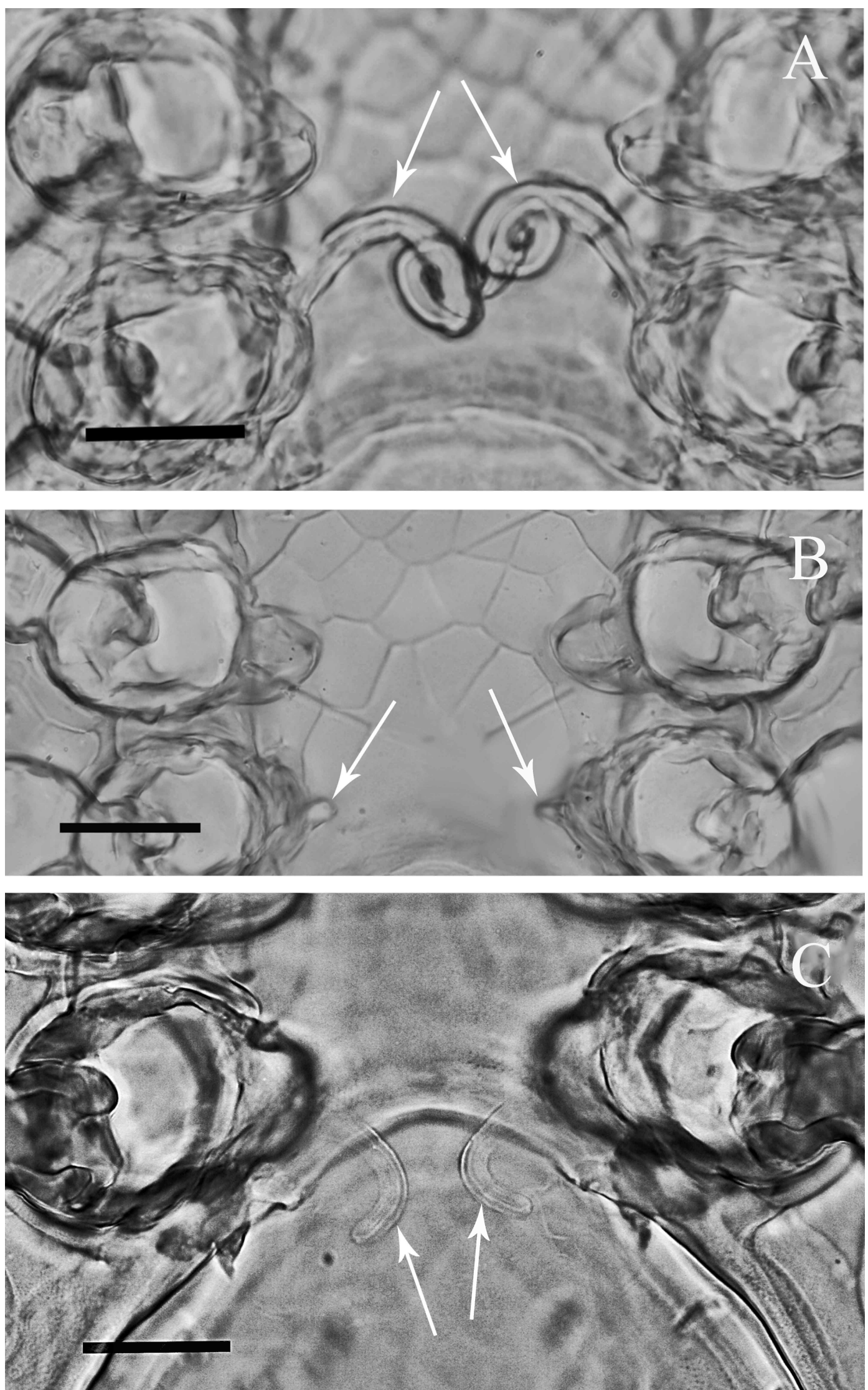

Figure 4 Tubes of the sperm access systems: A - Olopachysc ompositus; B - Olopachys caucasicus; C - Olopachys iraniensis n. sp. Scale bar: $50 \mu \mathrm{m}$ 
iraniensis n. sp., O. compositus Koroleva, 1976 and O caucasicus Koroleva, 1976 were examined, characteristics of other species were obtained from literature.

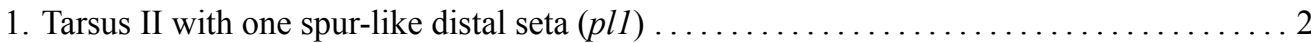

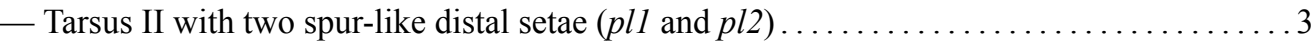

2. Genitiventrianal shield with three pairs of setae (st5, JV1, JV2); metapodal sclerites small

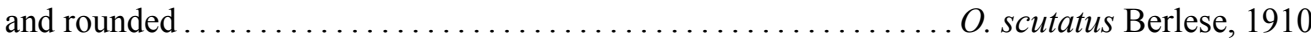
- Genitiventrianal shield with five pairs of setae (st5, JV1, JV2, ZV2, ZV3); metapodal sclerites

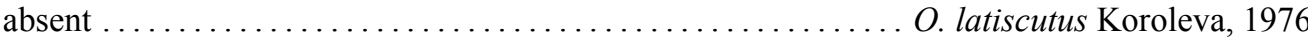

3. Postero-lateral margins of dorsal shield with one pair of gland pores $(g d S 4) \ldots \ldots \ldots \ldots 4$

— Postero-lateral margin of dorsal shield with two pairs of gland pores $(g d S 4, g d Z 1) \ldots \ldots 2$

4. Tubes of sperm access system very long, helically arranged, and longer than distance

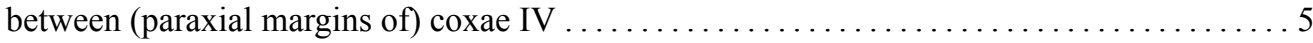
- Tubes of sperm access system short, not helically arranged, and shorter than distance between

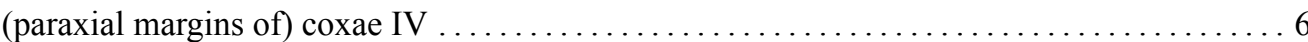

5. Tubes of sperm access system with uniform shape over their length; dorsolateral and opisthogastric soft integument with 13 pairs of setae [six pairs of r. R. $(r 6, R 1, R 3, R 5-7)] \ldots$ O. suecicus Sellnick, 1950

- Tubes of sperm access system with two regions of distinct thicknesses, the basal part (close to coxa IV) is thick and crescent-shaped and anterior part is slender and long; dorsolateral and opisthogastric soft integument with 14 pairs of setae [seven pairs of r. R. $(r 6, R 1, R 3-7)] \ldots$ O. crescentus Özbek, 2016

6. Dorsolateral and opisthogastric soft integument with 14 pairs of setae [seven pairs of r. R. $(r 6, R 1, R 3-7)]$; ratio of length/width of genitiventrianal shield $>1.5(1.54-1.69)$.

O. elongatus Özbek and Halliday, 2015

- Dorsolateral and opisthogastric soft integument with at most 13 pairs of setae; ratio of

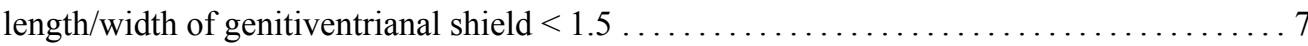

7. Dorsolateral and opisthogastric soft integument with at least 12 pairs of setae $\ldots \ldots \ldots 8$

- Dorsolateral and opisthogastric soft integument with at most 11 pairs of setae.......11

8. Soft integument with at least 13 pairs of marginal and opisthogastric setae .........9

— Soft integument with 12 pairs of marginal and opisthogastric setae $\ldots \ldots \ldots \ldots \ldots \ldots$

9. Tubes of sperm access system with a dark-brown part in apical, soft integument with six pairs of r. R. (r6, R1, R3-R6) and seven pairs of opisthogastric ( JV3-JV5, ZV1, ZV3-ZV5)

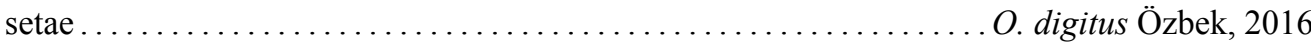
- Tubes of sperm access system without dark-brown part in apical, soft integument with eight pairs of r. R. $(r 6, R 1, R 3-R 8)$ and six pairs of opisthogastric ( $J V 3-J V 5, Z V 2-Z V 4)$ setae...

O. iraniensis n. sp.

10. Tubes of sperm access systems short, well sclerotized and with ductus well indicated and observable; gland pore $g d S 4$ between setae $Z 2$ and $S 4$; pre-anal setae $J v 2$ connected by a

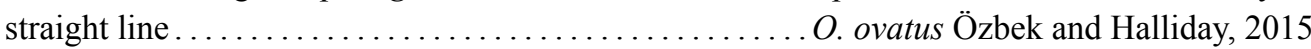
- Tubes of sperm access systems longer, weakly sclerotized and with ductus inconspicuous, difficult to discern; gland pore $g d S 4$ and setae $S 4$ aligned transversally; pre-anal setae $J v 2$ not 
connected by a straight line

O. vlastae Mašán, 2007

11. Soft integument with 11 pairs of marginal and opisthogastric setae; tubes of sperm access system thin and slightly curved $\ldots \ldots \ldots \ldots \ldots \ldots \ldots \ldots$. vysotskajae Koroleva, 1976 - Soft integument with 10 pairs of marginal and opisthogastric setae; tubes of sperm access system thick, strongly recurved, hook-shaped O. prolixus Özbek and Halliday, 2015

12. Tubes of sperm access system very long, with several bends; length of dorsal shield 730-840 O. compositus Koroleva, 1976

— Tubes of sperm access system short or normal in length, without bends $\ldots \ldots \ldots \ldots \ldots 13$

13. Tubes of sperm access system thick and strongly sclerotized $\ldots \ldots \ldots \ldots \ldots \ldots \ldots \ldots$

— Tubes of sperm access system thin and weakly sclerotized $\ldots \ldots \ldots \ldots \ldots \ldots \ldots \ldots$

14. Metapodal plates fused with lateral margins of genitiventrianal shield . . . . . . . . 15

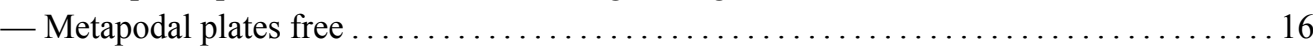

15. Tubes of sperm access system short and uniform in width; genitiventrianal shield with

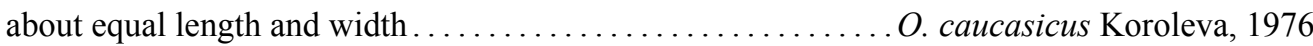
— Tubes of sperm access system long and expanded apically; genitiventrianal shield longer than wide (length/width 1.12) O. hallidayi Özbek, 2014

16. Tubes of sperm access system expanded apically O. adsharicus Koroleva, 1976

— Tubes of sperm access system uniform in width

17. Tubes of sperm access system longer, apically reaching each other; sternal area between st 2 and st 3 with sculptural transverse line; lateral and opisthogastric integument with 11 pairs

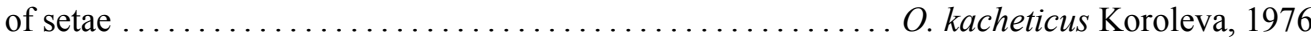
- Tubes of sperm access system shorter, apically not reaching each other; sternal area between st 2 and st 3 without sculptural transverse line; lateral and opisthogastric integument with 13

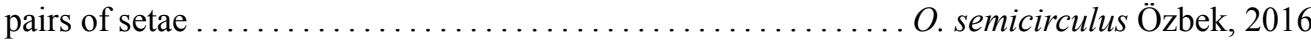

18. Dorsal setae shorter ( $J 4$ 90-110); length of dorsal shield 650-730; geniti-ventrianal shield approximately subequal in length and width (length $0.34-0.39$, width $0.33-0.36$ ); tubes of sperm access system opening near coxae IV .............. O. annae Koroleva, 1976

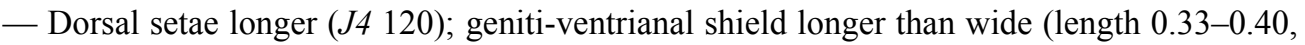
width $0.30-0.34)$; tubes of sperm access system opening between coxae III and IV

19. Genu and tibia of legs III and IV with small tubercles; tubes of sperm access system with broadened base ................................ golubevi Reitblatt, 1958 — Genu and tibia of legs III and IV without tubercles; tubes of sperm access system relatively thin in basal part.................................. sklari Koroleva, 1976

\section{Key to species (females) of the genus Olopachys Berlese occurring in Iran}

1. Tubes of sperm access system quite long, spiralled apically (Figure 4A) .... O. compositus Koroleva, 1976

- Tubes of sperm access system short (Figure 4B) or normal in length, straight or moderately

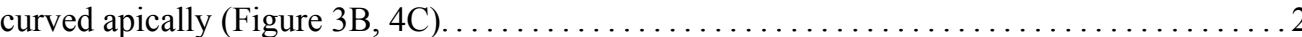


2. Tubes of sperm access system much shorter than distance between (paraxial margins of) coxae IV, and uniform in widths, without bends (Figure 4B); metapodal plates fused with lateral margins of genitiventrianal shield .............. O. caucasicus Koroleva, 1976 - Tubes of sperm access system longer, approximately as long as distance between coxae IV, slightly tapered and strongly curved apically (Figures 3B, 4C); metapodal plates free

Olopachys iraniensis n. sp.

\section{Remarks on Pachylaelapidae of Iran}

The fauna of Pachylaelapidae in Iran is poorly known. So far, 25 species of pachylaelapid mites from four genera are known from Iran (20 species recorded and five species described). The complete identification of mites of the family Pachylaelapidae in Iran requires additional studies in the future. Tabulated checklist of Iranian pachylaelapid mite species based on their genera is as follow (Table 1).

Table 1 Checklist of the Iranian Pachylaelapid mite species (described species are marked by an asterisk above their names).

\begin{tabular}{|c|c|c|}
\hline No. & Species & Related references \\
\hline 1 & Olopachys caucasicus Koroleva & Ahangaran et al . 2010 \\
\hline 2 & Olopachys compositus Koroleva & Kazemi and Ahangaran 2011 \\
\hline 3 & Olopachys iraniensis n. sp. ${ }^{*}$ & This study \\
\hline 4 & Onchodellus alpinus (Willmann) & Rahmani et al . 2006 \\
\hline 5 & Onchodellus glandularis (Moraza and Peňa) & Ahadiyat and Cheraghali 2012 \\
\hline 6 & Onchodellus hispani (Berlese) & Ahmadi 2002 \\
\hline 7 & Onchodellus karawaiewi (Berlese) & Khanjani and Kamali 2000a, b \\
\hline 8 & Onchodellus procerus Mašán & Nazari-Tajani et al . 2012 \\
\hline 9 & Onchodellus siculus (Berlese) & Ahmadi 2002 \\
\hline 10 & Onchodellus squamosus (Koroleva) & Mojahed et al . 2017 \\
\hline 11 & Onchodellus strigifer (Berlese) & Ahadiyat and Cheraghali 2012 \\
\hline 12 & Pachylaelaps brachiosus Hirschmann and Krauss & Jalaeian et al . 2004 \\
\hline 13 & Pachylaelaps costai Hirschmann and Krauss & Jalaeian et al . 2004 \\
\hline 14 & Pachylaelaps grandis Koroleva & Ahadiyat and Cheraghali 2012 \\
\hline 15 & Pachylaelaps imitans Berlese & Ahmadi 2002 \\
\hline 16 & Pachylaelaps magnus Halbert & Ahmadi 2002 \\
\hline 17 & Pachylaelaps pectinifer (G. Canestrini) & Jalaeian et al . 2004 \\
\hline 18 & Pachylaelaps resinae Karg & Kamali et al . 2001 \\
\hline 19 & Pachylaelaps insularis (Berlese) & Ahangaran et al . 2012 \\
\hline 20 & Pachylaelaps (Longipachylaelaps) vicarius Mašán & Ahadiyat et al . 2014 \\
\hline 21 & Pachylaelaps prodigiosus Mašán et al. 2018 & Mašán et al . 2018 \\
\hline 22 & Pachyseius angustus Hyatt & Babaeian \& Kazemi 2011 \\
\hline 23 & Pachyseius masanisimilis* Ahadiyat and Ghasemi Moghadam & Ahadiyat et al . 2016 \\
\hline 24 & Pachyseius persicus * Babaeian and Mašán & Babaeian et al . 2016a \\
\hline 25 & Pachyseius angustoides* Babaeian \& Mašán & Babaeian et al . 2016b \\
\hline
\end{tabular}




\section{Acknowledgments}

We wish to thank Dr. Peter Mašán (Institute of Zoology, Slovak Academy of Sciences) for having examined specimens of selected species and advice, and Dr. Bruce Halliday (CSIRO Entomology, Canberra, Australia) for a preliminary review of the manuscript and advice.

\section{References}

Ahadiyat A., Cheraghali Z. 2012. Faunistic study of pachylaelapid mites (Mesostigmata: Eviphidoidea: Pachylaelapidae) in Roodbaar-Ghasraan region (Shemiraanaat county) of Tehran province. In: Sarafrazi A., Asef M.R., Mozhdehi M., Mozhdehi M., Solhjouy Fard S., Abdollahi T. (Eds.). Proceeding of 20th Iranian Plant Protection Congress; Shiraz University, Shiraz, Iran. p. 428.

Ahadiyat A., Mašán P., Cheraghali Z., Joharchi O. 2014. First report of the subgenus Pachylaelaps (Longipachylaelaps) Mašán (Mesostigmata: Eviphidoidea: Pachylaelapidae) from Iran. Persian J. Acarol., 3(1): 99-102.

Ahadiyat A., Ghasemi Moghadam S., Cheraghali Z. 2016. Pachyseius masanisimilis (Mesostigmata: Eviphidoidea: Pachylaelapidae), a new species of edaphic mite from Iran. Persian J. Acarol., 5(2): 109-120.

Ahangaran Y., Afshari A., Saboori A., Kazemi Sh., Asadeh Gh. 2010. Introduction of some pachylaelapid mites (Acari: Mesostigmata) in Nowshahr Region. In: Manzari S. (Ed.). Proceeding of 19th Iranian Plant Protection Congress, Iranian Research Institute of Plant Protection, Tehran. p. 368

Ahangaran Y., Afshari A., Saboori A., Kazemi Sh. 2012. The fauna of the edaphic and dung dweller mites of the superfamily Eviphidoidea (Acari: Mesostigmata) in Nowshahr county, northern Iran. Taxon. Biosyst. J. Iran, 12: 1-16.

Athias-Henriot C. 1969. Les organes cuticulaires sensoriels et glandulaires des Gamasides. Poroïdotaxie et adénotaxie. Bull. de la Soc. Zoolog. de France, 94: 458-492.

Babaeian E., Kazemi Sh. 2011. Mites of the family Pachylaelapidae (Mesostigmata: Eviphidoidea) in Shahrekord region, Iran. In: Kazemi Sh., Saboori A. (Eds.). Proceeding of 1th Persian Congress of Acarology, International Center for Science, High Technology \& Environmental Sciences, Kerman. p. 43.

Babaeian E., Mašán P., Saboori A. 2016a. The genus Pachyseius Berlese, 1910 in Iran (Acari: Pachylaelapidae). Zootaxa, 4088(3): 420-428. doi:10.11646/zootaxa.4088.3.7

Babaeian E., Mašán P., Saboori A. 2016b. A new species of the genus Pachyseius Berlese (Acari: Pachylaelapidae) from Iran, with remarks on the world fauna. Persian J. Acarol., 5(4): 299-309.

Berlese A. 1910. Lista di nuove specie e nuovi generi di Acari. Redia, 6: 242-271.

Jalaeian M., Saboori A., Seyedoleslami H. 2004. Report of mesostigmatic mites in Iran. J. Entomol. Soc. Iran., 23(2): 125-126.

Evans G. O. 1963. Observations on the chaetotaxy of the legs in the free-living Gamasina (Acari: Mesostigmata). Bull. Br. Mus. nat. Hist. (Zool.), 10: 275-303. doi:10.5962/bhl.part.20528

Johnston D. E., Moraza M. L. 1991. The idiosomal adenotaxy and poroidotaxy of Zerconidae (Mesostigmata: Zerconina). In: Dusbábek F., Bukva V. (Eds.). Modern Acarology 2. Prague and SPB Academic Publishing. p. 349-356.

Kamali K., Ostovan H., Atamehr A. 2001. A catalog of mites \& ticks (Acari) of Iran. Tehran: Islamic Azad University Scientific Publication Center. pp. 205.

Karg W. 1993. Acari (Acarina), Milben Parasitiformes (Anactinochaeta), Cohors Gamasina Leach, Raubmilben. Die Tierwelt Deutschlands, 59: 1-523.

Kazemi Sh., Ahangaran Y. 2011. Soil-inhabiting Mesostigmata (Acari) of west Mazandaran province, Iran. In: Kazemi Sh., Saboori A. (Eds.). Proceeding of $1^{\text {th }}$ Persian Congress of Acarology, International Center for Science, High Technology \& Environmental Sciences, Kerman. p. 62.

Kazemi Sh., Ahangaran Y., Arjomandi E., Rajaei A. 2012. Some rare Gamasina (Acari: Mesostigmata) from Iran. Proceeding of 7th European Association of Acarologists Symposium, Vienna. p. 88

Kazemi Sh., Rajaei A. 2013. An annotated checklist of Iranian Mesostigmata (Acari), excluding the family Phytoseiidae. Persian J. Acarol., 2(1): 63-158.

Khanjani M., Kamali K. 2000a. A study of Acari fauna of clover (Trifolium sp.) in Hamedan. Proceeding of 14th Iranian Plant Protection Congress, Iranian Research Institute of Plant Protection; Isfahan. p. 234.

Khanjani M., Kamali K. 2000b. Mites (Acari) associated with beans (Phaseolus volgaris L.) in Hamedan province. Proceeding of 14th Iranian Plant Protection Congress, Iranian Research Institute of Plant Protection; Isfahan. p. 246.

Koroleva E. V. 1976. New species of mites of the genus Olopachys Berlese, 1910. Entomol. Obozr., 55: 480-496.

Koroleva E. V. 1977. Family Pachylaelaptidae Vitzthum, 1931. In: Ghilyarov M.S., Bregetova N.G. (Eds). Key to the Soil-inhabiting Mites, Mesostigmata, Nauka. Leningrad, pp. 411-483.

Lindquist E. E., Evans G. O. 1965. Taxonomic concepts in the Ascidae, with a modified setal nomenclature for the idiosoma of the Gamasina (Acarina: Mesostigmata). Mem. Entomol. Soc. Can., 47: 1-64. doi:10.4039/entm9747fv

Mašán P. 2007a. A review of the family Pachylaelapidae in Slovakia, with systematic and ecology of European species (Acari: Mesostigmata: Eviphidoidea). Bratislava: Institute of Zoology, Slovak Academy of Sciences. pp. 247. 
Mašán P. 2007b. Olopachys (Olopachylaella) gronychi subgen. nov., sp. nov., a new species of mite from Bulgaria (Acari: Mesostigmata: Pachylaelapidae). Zootaxa, 1509: 31-39.

Mašán P., Halliday B. 2014. Review of the mite family Pachylaelapidae (Acari: Mesostigmata). Zootaxa, 3776(1): 1-66. doi:10.11646/zootaxa.3776.1.1

Mašán P., Mojahed S., Hajizadeh J., Hosseini R., Ahadiyat A. 2018. On remarkable Pachylaelaps species with unusual sperm induction system in females (Acari, Mesostigmata, Pachylaelapidae). Syst. Appl. Acarol., 23(9): 1726-1740. doi:10.11158/saa.23.9.2

Mohammad-Dustar-Sharaf M., Mirfakhraie Sh., Zargaran M. R., Azimi N. 2016a. Species Diversity of Edaphic Mesostigmatid Mites (Acari: Mesostigmata) of Arasbaran Forest. For. Res. Dev. Iran, 2(1): 85-96.

Mohammad-Dustar-Sharaf M., Shirdel D., Mirfakhraie Sh. 2016b. Introduction to some edaphic mesostigmatic mites (Acari: Mesostigmata) from Arasbaran forests, north of East Azerbaijan Province. Appl. Res. Plant Prot. Iran, 5(2): 227-242.

Mojahed S., Hajizadeh J., Hosseini R., Ahadiyat A. 2017. Contribution to the Pachylaelapidae Berlese fauna (Acari: Mesostigmata) in some parts of Guilan Province, Persian J. Acarol., 6(4): 269-285.

Moraza M. L., Pena M. 2005. The family Pachylaelapidae Vitzthum, 1931 on Tenerife Island (Canary Islands), with description of seven new species of the genus Pachylaelaps (Acari, Mesostigmata: Pachylaelapidae). Acarologia, 45 (2/3): 103-129.

Nazari-Tajani M., Hajizadeh J., Noei J. 2012. First report of one pachylaelapid species (Mesostigmata: Pachylaelapidae) from Iran. In: Sarafrazi A., Asef M.R., Mozhdehi M., Mozhdehi M., Solhjouy Fard S., Abdollahi T. (Eds.). Proceeding of 20th Iranian Plant Protection Congress; University of Shiraz. p. 510.

Özbek H. H. 2014. A new species of Olopachys Berlese (Acari: Pachylaelapidae) from north-eastern Turkey. Int. J. Acarol., 40: 328-331. doi:10.1080/01647954.2014.916748

Özbek H. H. 2016. Three new species of mites in the genus Olopachys (Acari: Pachylaelapidae) from Trabzon and Artvin Provinces, Turkey. Syst. Appl. Acarol., 21(5): 657-671. doi:10.11158/saa.21.5.7

Özbek H. H., Halliday B. 2015. Four new species of Olopachys Berlese from Turkey (Acari: Pachylaelapidae), with a key to the world species. Syst. Appl. Acarol., 30: 139-152. doi:10.11158/saa.20.1.13

Zakeri V., Kamali K., Hajiqanbar H. R. 2012. Coprophage and edaphic mites of the families Macrochelidae and Pachylaelapidae in eastern region of Golestan Province, Iran. Plant Pest Res. Iran, 1(1): 17-23.

Reitblatt A. G. 1958. A new species of gamasid mite of the genus Olopachys (Parasitiformes, Gamasoidea). Parazitol. Sb., 18: 180-182.

Rezaie F., Ahadiyat A., Joharchi O., Bahrami F. 2016. Mesostigmata mites order associated with insects of North Khorasan Province. In: Talaei-Hassanloui R. (Ed.). Proceeding of 22th Iranian Plant Protection Congress; University of Tehran. p. 512.

Saberi S., Kazemi Sh., Ahadiyat A. 2016. Edaphic mites of the cohort Gamasina (Acari: Mesostigmata) in the Ecological Garden of Nowshahr, Iran. Persian J. Acarol., 5(2): 121-130.

Sellnick M. 1950. Eine neue Olopachys Art aus Schweden. Entomol. tidskr., 71: 9-14. 